\title{
Die morele genesing van die Suid-Afrikaanse samelewing: Die bydrae van die Afrikaanse
}

\section{kerke}

Etienne de Villiers

Departement Dogmatiek en Christelike Etiek

Universiteit van Pretoria

\begin{abstract}
The moral healing of the South African society: the contribution of the Afrikaans churches

In this article an attempt is made to determine the potential contribution of the Afrikaans churches to the moral healing of the South African society. In order to do this an analysis is first of all made of the characteristics, as well as the causes, of the present moral crisis we are experiencing in South Africa. In the light of the multifaceted nature of the moral crisis and its causes, a multifaceted approach by the Afrikaans churches is recommended. Note is also taken of the unique position of the Afrikaans churches and the limitations and challenges which this position entails.
\end{abstract}

\section{INLEIDING}

Oor die aanwesigheid van 'n ernstige morele krisis in ons samelewing bestaan daar 'n groot mate van konsensus. Dit is die een saak waaroor selfs president Thabo Mbeki en opposisieleiers dit met mekaar eens is. Oor wie of wat nou eintlik vir die morele krisis verantwoordelik is, loop die menings egter sterk uiteen. Oor die oplossing vir die morele krisis bestaan daar net so min eenstemmigheid.

Die doel van hierdie artikel is om die bydrae wat die Afrikaanse kerke tot die bestryding van die morele krisis, of - om dit meer positief te stel - tot die morele genesing van die Suid-Afrikaanse samelewing kan lewer, vas te stel. Geen effektiewe oplossing vir 
die morele krisis kan egter gevind word as daar nie eers duidelikheid is oor die aard van dié krisis en die faktore wat daartoe ' $n$ bydrae lewer nie. Daarom word eers 'n poging aangewend om so 'n noukeurig moontlike beeld te kry van die gelaat en die oorsake van die morele krisis.

\section{DIE GELAAT VAN DIE MORELE KRISIS}

As ons die morele krisis in ons samelewing beskryf, moet ons waak teen twee eensydighede. Al sou dit verkeerd wees om die erns van die huidige morele krisis te misken, moet ons eerstens daarteen waak om die indruk te wek dat dit op die gebied van moraliteit in alle opsigte veel slegter gaan as in die verlede. In meerdere opsigte gaan dit beslis beter as in die verlede. Ons het die apartheidsbeleid, die regering deur ' $n$ minderheid en die gewapende stryd tussen die regering en die bevrydingsbewegings in die vorige politieke bedeling agter ons gelaat. Die nuwe grondwet en die konstitusionele hof het daartoe bygedra dat daar reeds 'n veel sterker menseregtekultuur as vroeër in ons samelewing gevestig is.

'n Tweede eensydigheid waarteen ons moet waak, is om die morele krisis in ons samelewing slegs in terme van die toename in misdaad te beskryf. Die neiging bestaan om uitsluitlik na die toename in geweldsmisdaad (moorde, aanrandings, skakings, gewapende roof en verkragtings) en na witboordjiemisdaad (bedrog en korrupsie ${ }^{1}$ ) te verwys as van die morele krisis gepraat word. Dit bring teweeg dat die oplossing vir die morele krisis ook eensydig gesien word in die invoering van strenger wette (bv die instelling van swaarder strawwe en strenger kontrolemaatreëls oor staatsfinansies) en beter wetstoepassing (bv meer effektiewe polisie-optrede, beter funksionering van die howe en die uitskakeling van ontsnappings).

Die morele krisis in ons samelewing lê veel dieper en is veel meer omvattend as die hoë voorkoms van misdaad. Die misdaad is slegs die punt van die ysberg van ons morele krisis. Die gebrekkige morele kwaliteit van baie huweliks- en gesinsverhoudings (die hoë voorkoms van egskeidings, buite-egtelike verhoudings, geweldsaanwending teen huweliksmaats en kinders en die seksuele misbruik van kinders) maak ook deel uit van die morele krisis. So ook die baie voorbeelde van laksheid by onderwysers, verpleegsters en ander beroepsgroepe in die uitoefening van hulle beroepspligte waarvan ons in die koerante lees.

\footnotetext{
1 Vgl W C Esterhuyse, "Die baie gesigte van korrupsie", Beeld 10 Maart 1999, vir 'n goeie oorsig van die verskillende vorme van korrupsie in Suid-Afrika.
} 
Die groeiende aantal mense wat HIV geïnfekteer is, hang onlosmaaklik saam met grootskaalse losbandige seksuele gedrag.

Wend ' $n$ mens 'n poging aan om die morele krisis te ontleed, kom 'n mens gou onder die indruk hoe ' $n$ ingewikkelde verskynsel dit eintlik is. Die morele krisis bestaan deels daarin dat Suid-Afrikaners uiteenlopende opvattings huldig oor wat moreel reg en verkeerd is (vgl Van Niekerk 1992:5-11; Painter-Morland 1999:149-162). Dit bestaan ook in die opvallende onvermoë van baie om dit wat hulle as moreel juiste optrede sien, ook daadwerklik uit te leef. Daarby kom die bewustelike verset van sommige teen die oorgelewerde moraal van die kulturele of godsdienstige groepe waartoe hulle behoort. Wat ook opvallend is, is die toenemende onsekerheid wat baie mense ervaar oor wat nou eintlik moreel reg en verkeerd is. ${ }^{2}$

Die morele krisis hang ook in 'n belangrike mate saam met 'n meer diepliggende bestaanskrisis. Daar is baie mense in ons samelewing wat nie die wil het om moreel reg op te tree nie, omdat hulle omstandighede so haglik is, hulle alle respek vir die lewe en besittings van medemense verloor het, hulle alle hoop vir die toekoms verloor het, of hulle in 'n geloofskrisis verkeer.

\section{DIE OORSAKE VAN DIE MORELE KRISIS}

Ons kan onderskei tussen oorsake van die morele krisis wat reeds in die verlede 'n rol gespeel het en ander wat spruit uit die oorgang na 'n nuwe politieke bedeling of, as gevolg daarvan, nou 'n groter invloed uitoefen.

Tot die oorsake uit die verlede behoort die grootskaalse armoede en ekonomiese ongelykheid in ons samelewing. Alle mense wat onder die broodlyn lewe, is beslis nie skelms nie. Die versoeking om te lieg en te bedrieg om te kan oorleef, is vir hulle egter veel sterker as vir diegene wat genoeg het om van te leef. Verstedeliking, asook die stelsel van trekarbeid, het 'n ontwrigting van die tradisionele gemeenskapslewe en die gesinslewe teweeggebring en die gebondenheid van baie mense aan tradisionele waardes afgebreek.

\footnotetext{
${ }^{2}$ Hierdie onsekerheid het 'n tipiese kenmerk geword van die tyd waarin ons leef. Die Belgiese filosoof Herman de Dijn (1997:37) wys daarop dat dit uitloop op 'n situasie waarin elkeen self uitmaak wat hy of sy wil doen: "We leven ... in een narcistische cultuur waarin het individu zelf zijn leven organiseert naar eigen goeddunken en op experimentele basis. Het veelbesproken individualisme gaat samen met relativisme (ieder moet zelf beslissen wat voor hem het beste is; de grens is de tolerantie van andermans zelfbeschikkingsrecht)."
} 
Die normale vorming van morele waardes wat in stabiele gemeenskappe veral in gesinne en skole, en deur deelname aan godsdienstige aktiwiteite en die gemeenskapslewe geskied, is deur hierdie ontwrigting sterk in die wiele gery. Nog 'n faktor is die kultuur van geweld wat veral in swart woonbuurte ontstaan het, onder andere as gevolg van die jarelange stryd in die vorige politieke bedeling tussen die regering en die bevrydingsbewegings. Die opskorting van morele oortuigings (bv dat 'n mens nie mag doodslaan of martel nie) terwille van die verdediging van die groter saak van die verdediging van die "Christelike beskawing", of terwille van die bevrydingstryd, is nog'n faktor. En dan is daar nog die oorblyfsels van 'n hardnekkige rassisme (die minagting van mense van 'n ander kleur) en van haat teenoor diegene wat vir soveel jare as die vyand beskou is.

Ander oorsake het meer op die hede betrekking. Die ingrypende transformasieproses wat in ons samelewing plaasvind, het by baie blankes groot onsekerheid tot gevolg gehad: onsekerheid oor hulle eie identiteit en rol in die nuwe bedeling; onsekerheid ook oor hulle en hulle kinders se veiligheid en finansiële en werksvooruitsigte. By baie het dit aanleiding gegee tot ' $n$ negatiewe en na binne gekeerde ingesteldheid ${ }^{3}$ en by sommige tot ' $n$ houding van: vat terwyl jy nog die geleentheid het om te vat. Die oorgangstydperk het ook baie swartmense onkant gevang. Baie van hulle wat daaraan gewoond was om die vorige regering te beveg, het hulleself skielik in verantwoordelike posisies in die regering, staatsdiens of besigheid bevind. Die gebrek aan ondervinding en soms ook aan bekwaamheid, het van hulle daartoe verlei om 'n valse front voor te hou en immorele kortpaaie te neem. Ander kon die versoeking om hulle nuutverworwe magsposisie te misbruik en hulleself te verryk en hulle familie te bevoordeel, nie weerstaan nie. Die rasionalisering dat hulle die reg het om - op watter manier dan ook - op te maak vir wat hulle en hulle families in die verlede misgun is, het hulle handig te pas gekom.

Die invoering van 'n nuwe, liberale grondwet lewer ook 'n bydrae. Aangesien 'n skerper skeiding tussen kerk en staat as in die verlede voorgestaan word, is dit nie meer vir kerke moontlik om - soos die Afrikaanse kerke in die verlede - 'n sterk behoudende invloed

\footnotetext{
${ }^{3}$ Moltmann (1974:37-41) tipeer hierdie ingesteldheid as "innerlike emigrasie". Innerlike emigrasie word gemotiveer deur passiewe opposisie teen onpopulêre of afkeurenswaardige ontwikkelinge in die samelewing daarbuite. Met die hulp van 'n private kring, 'n eiland van innerlike emigrasie en ironiese opmerkings oor die situasie verkry sulke mense 'n staanplek buite die openbare "ellende" en skep hulle vir hulself afstand teenoor die alledaagse lewe.
} 
op wetgewing wat openbare sedelikheid reël, uit te oefen nie. Die liberalisering van 'n hele reeks van hierdie wette (o a wette wat aborsie, dobbelary en pornografie verbied het) het die greep van 'n behoudende moraal op die openbare lewe finaal gebreek. Die groter klem wat op grond van die handves van menseregte in die huidige samelewing op vryheid van godsdiens, oortuiging en mening en vryheid van uitdrukking geplaas word, bring teweeg dat kerklidmate nou veel meer as voorheen blootgestel word aan die afwykende morele sieninge van ander godsdienstige en lewensbeskoulike groepe (vgl De Villiers 1999:19-21).

Die nuwe grondwetlike bedeling het tot gevolg dat die prosesse van modernisering (die tendens om alle probleme slegs met behulp van die rede op te los) en van sekularisasie (die tendens dat ander lewensterreine, soos die politiek en die ekonomie, hulle aan die invloed van die kerk en Christelike godsdiens onttrek) nou vinniger as voorheen in ons samelewing voltrek word. ${ }^{4}$ Selfs lidmate vra hulleself steeds meer af of die boodskap van die kerk nog enigsins relevansie in die politiek, die ekonomie en die werkplek het. Hulle begin steeds meer kritiese vrae stel oor die oorgelewerde kerklike moraal, soos byvoorbeeld die afwysing van saamwonery en die afwysing van alle homoseksuele gedrag.

Die morele onsekerheid by kerklidmate - en in die samelewing as geheel - word ook versterk deur die groeiende invloed van waardes wat in die vryemarkekonomie 'n sentrale rol speel (vgl Mudge 1998:54-56). Die onaanvegbare posisie van die vryemarkekonomie, ook in Suid-Afrika, bring teweeg dat waardes soos kompetisie, die doelgerigte nastrewe van eiebelang, die vermeerdering van materiële besittings en ' $n$ verbruikersmentaliteit - waardes wat moeilik met oorgelewerde Christelike waardes gerym kan word onkrities deur baie kerklidmate uit alle bevolkingsgroepe oorgeneem word. Die vraag kan tereg gestel word of die groot invloed van materialistiese waardes in ons samelewing nie ook ' $n$ belangrike bydrae lewer tot die toenemende korrupsie, bedrog en diefstal in die samelewing nie.

\footnotetext{
${ }^{4}$ Van der Ven (1993:18-31) bied ' $n$ indringende bespreking van modernisering as konteks van die' kerk in moderne samelewings in Ecclesiologie in context. Hy omskryf modernisering as: "de maatschappelijke ontwikkeling die gekenmerk wordt door het streven om problemen vanuit het perspectief van de rationaliteit op te lossen" (Van der Ven 1993:18).
} 


\section{DIE BYDRAE VAN DIE AFRIKAANSE KERKE TOT DIE MORELE GENESING VAN ONS SAMELEWING}

Nie almal sal saamstem dat die Afrikaanse kerke wel 'n bydrae tot die morele genesing van die samelewing kan en behoort te lewer nie. Diegene wat die vermoë van die Afrikaanse kerke om 'n bydrae te lewer bevraagteken, kan daarop wys dat dié kerke nie meer die groot invloed op die openbare lewe het wat hulle vroeër gehad het nie. Daarby is daar nog steeds mense wat dit moeilik vind om hulle geloofwaardigheid te aanvaar en met hulle saam te werk vanweë die ondersteuning wat hulle aan die apartheidsbeleid gebied het. Bowendien is dit 'n vraag of hulle die wil het om 'n sterk positiewe bydrae tot die morele genesing van ons samelewing te lewer. Baie lidmate voel bedreig deur wat in die samelewing gebeur. Hulle het nie behoefte daaraan om by allerlei kerklike projekte in die samelewing betrokke te raak nie - hoe goed die bedoelinge daarvan ook al is. Hulle behoefte is veel eerder om in die veilige beskutting van hulle eie kerk vertroosting te vind teen die aanslae wat hulle daagliks in die samelewing ervaar.

Diegene wat wonder of die Afrikaanse kerke 'n bydrae tot die morele genesing van ons samelewing behoort te lewer, kan daarop wys dat die Afrikaanse kerke reeds eenmaal hulle vingers met morele leiding verbrand het toe hulle apartheid as die oplossing vir ons land se probleme voorgehou het. Sou, in die lig daarvan, 'n meer terughoudende houding ten aansien van die huidige morele krisis nie gepas wees nie? 'n Beroep kan selfs op die bekende Amerikaanse teoloog Stanley Hauerwas gedoen word om kerklike inisiatiewe in die huidige samelewing morele waardes te bevorder, te bevraagteken. Na sy mening is dit bykans onmoontlik vir 'n kerk om in liberale samelewings soos die VSA te stry vir byvoorbeeld sosiale geregtigheid sonder om die liberale opvatting van geregtigheid as uitgangspunt te neem. Vanweë die skerp skeiding tussen staat en godsdiens word geregtigheidsbeskouinge wat eiesoortig aan godsdienste is, nie in die openbare lewe geduld nie. Alleen die liberale geregtigheidsbeskouing wat algemeen insigtelik sou wees, word in die openbare lewe aanvaar. Stry die kerk egter vir sosiale geregtigheid, in die liberale sin van dié woord, bevorder die kerk nie die saak van Christus nie, maar die saak van die politieke liberalisme (Hauerwas 1991:45-68). Sou dieselfde nie geld vir kerke in Suid-Afrika waar 'n nuwe liberale grondwet geldig is nie? 
Die bydrae wat die Afrikaanse kerke tot die morele genesing van die SuidAfrikaanse samelewing kan lewer, moet ongetwyfeld nie oorskat word nie. Hulle deel met ander kerke ' $n$ inperking van openbare invloed vanweë die skeiding van kerk en staat wat ons grondwet voorstaan en die groter invloed van die moderniserings- en sekularisasieprosesse in ons samelewing. Daarby sal hulle eers hulle geloofwaardigheidsprobleem en die onwil van baie van hulle lidmate om 'n konstruktiewe rol in die nuwe Suid-Afrika te speel, uit die weg moet ruim as hulle wel ' $n$ beduidende bydrae tot morele genesing wil lewer.

Dit neem egter nie weg nie dat hulle wel 'n bydrae kan lewer. Alhoewel die huidige liberale grondwet ongetwyfeld 'n groter afstand tussen die staat en godsdienstige instellinge plaas, sluit dit - anders as die grondwet van die VSA - nie alle moontlikhede vir kerke om in die openbare lewe op te tree en 'n morele invloed uit te oefen, uit nie. Onder bepaalde voorwaardes kan godsdiensoefening nog steeds by staatsondersteunde instellings geskied ${ }^{5}$ - iets wat nie in die VSA toegelaat word nie. Alhoewel daar op lewensterreine soos die politiek, die ekonomie, die wetenskap en die kultuur nou sterker weerstand is teen die openbare getuienis van kerke, het lidmate van die Afrikaanse kerke nog steeds die geleentheid om op dié terreine 'n positiewe morele invloed uit te oefen. Deur gewilligheid te toon om saam met ander kerke te werk in die bestryding van ons morele krisis, kan die Afrikaanse kerke reeds baie doen om hulle geloofwaardigheidsprobleem te oorkom. Deur die onwil van lidmate om 'n konstruktiewe rol in die nuwe Suid-Afrika te speel, nie as 'n onveranderlike gegewe te anvaar nie, maar werk te maak van die faktore wat tot dié negatiewe ingesteldheid bydra, kan die bydrae van die Afrikaanse kerke tot die morele genesing eweseer versterk word.

Dit is ongetwyfeld so dat dit nie gepas sou wees as die Afrikaanse kerke, vanweë hulle apartheidsverlede, sou pretendeer dat hulle die oplossing vir die morele krisis in ons samelewing in pag het nie. Die een groot fout wat hulle gemaak het, onthef hulle egter nie van die verantwoordelikheid om 'n eie bydrae te maak nie. Hulle sal wel steeds weer moet seker maak dat die voorstelle wat hulle makk, ook vir ander kerke aanvaarbaar is. Ook om dié rede is ekumeniese samewerking onontbeerlik.

\footnotetext{
${ }^{5}$ Vergelyk Artikel 15(2) van die Handves van Regte in Die Grondwet van die Republiek van Suid-Afrika, 1996.
} 
Wat nou egter van die beroep op Stanley Hauerwas? So 'n beroep is slegs gedeeltelik geregverdig. Hy het nooit ontken dat die kerk 'n positiewe morele invloed in die samelewing kan uitoefen nie. Hy het alleen betwyfel dat die kerk dié invloed kan uitoefen deur in die openbare lewe vir die verandering van die samelewing te ywer. In plaas van om te probeer om die samelewing te verander deur allerlei sosiaal etiese inisiatiewe in die openbare lewe te onderneem, moet die kerk, na sy mening, eerder die voorbeeld stel van hoe 'n ware gemeenskap daar uitsien: "The task of the church [is] to pioneer those institutions and practices that the wider society has not learned as forms of justice ... The church, therefore, must act as a paradigmatic community in the hope of providing some indication of what the world can be, but is not ... The church does not have, but rather is a social ethic. That is, she is a social ethic inasmuch as she functions as a criteriological institution - that is, an institution that has learned to embody the form of truth that is charity as revealed in the person and work of Christ" (Hauerwas 1977:142-143).

'n Mens moet Hauerwas gelyk gee dat die belangrikste bydrae wat kerke tot morele genesing in liberale demokrasieë kan lewer, is om moreel voorbeeldige gemeenskappe te wees. In die geval van die Afrikaanse kerke kom ook nog daarby dat hulle deur hulle voorbeeld ' $n$ veel meer geloofwaardige bydrae tot 'n moreel gesonde samelewing kan lewer as deur skerp kritiek op byvoorbeeld die vermeende bydrae van staatsdiensamptenare tot die morele krisis in ons samelewing.

Die vraag is egter of die Afrikaanse kerke daarmee kan volstaan. In die bespreking van die oorsake van die huidige morele krisis is daarop gewys dat daar 'n aantal faktore in ons samelewing werksaam is wat nie bevorderlik vir morele optrede is nie. Een van dié faktore is die grootskaalse armoede. 'n Ander is die grootskaalse ontwrigting van gesinne en gemeenskappe. Nog 'n baie belangrike faktor is die sekularisasieproses. Dit lei daartoe dat lewensterreine soos die politiek en ekonomie onttrek aan die invloed van die kerk en daarom ook nie vatbaar is vir die morele voorbeeld van die kerk nie. Dit lei ook daartoe dat selfs lidmate nie in staat is om morele oortuigings en houdings wat in die kerk gevorm is, in die werkplek uit te leef nie. Baie van hulle leef 'n soort tweerykeleer prakties uit, deurdat hulle 'n skerp skeiding maak tussen hulle persoonlike en kerklike lewe waar Christelike waardes geld en hulle openbare lewe waar heeltemal ander spelreëls geld. Hierdie faktore sal ewe-eens deur die Afrikaanse kerke gehanteer moet word indien hulle ' $n$ betekenisvolle bydrae tot die morele herstel van die Suid-Afrikaanse samelewing wil lewer. 
Wat is nou egter meer konkreet die bydrae wat die Afrikaanse kerke tot die morele genesing van die Suid-Afrikaanse samelewing kan lewer? In die res van die artikel gaan ek eerstens aandag gee aan enkele inisiatiewe wat hulle na buite in die samelewing kan onderneem. Die grootste bydrae wat hulle kan lewer, is egter deur die moreel vormende invloed wat hulle op hulle eie lidmate kan hê. Daarom gaan tweedens meer uitvoerig aandag gegee word aan die Afrikaanse kerke se verantwoordelikheid om hulle eie lidmate moreel te vorm.

\subsection{Inisiatiewe in die samelewing}

- Dit is deel van die profetiese taak van die kerk om moreel onverantwoordelike of onaanvaarbare gedrag of beleid wat sulke gedrag bevorder, waar te neem, te ontleed en te kritiseer. Vanweë die feit dat daar nog steeds mense is wat die geloofwaardigheid van die Afrikaanse kerke bevraagteken, moet groot takt in die uitoefening van dié profetiese kritiek aan die dag gelê word. Dit sal beter wees as die Afrikaanse kerke in dié verband ekumeniese samewerking met ander kerke soek en saam met hulle profetiese kritiek lewer as dit nodig is. In elk geval sal sulke kritiek in die huidige liberale Suid-Afrikaanse samelewing slegs effektief wees as kerke uit een mond praat ( $\mathrm{d} i$ as die kritiek ekumeniese konsensus uitdruk). Nog 'n vereiste is dat dié kritiek deeglik begrond moet word, en dat dit aangebied word in taal en argumente wat ook deur nie-Christene verstaan kan word. ${ }^{6}$ Indien die profetiese kritiek van kerke aan dié vereistes voldoen, kan dit nog steeds invloed op die openbare mening uitoefen.

- Die profetiese taak van die kerk sluit ook positiewe waardering van moreel verantwoordelike gedrag en beleidsmaatreëls wat moreel verantwoordelike gedrag in die samelewing bevorder, in. Die Afrikaanse kerke moenie skroom om die inisiatiewe wat die regering en baie besighede nou neem om bedrog en korrupsie te beveg, te ondersteun nie. Hierdie ondersteuning hoef nie kritiek uit te sluit nie. Daar is op die

\footnotetext{
${ }^{6}$ Vergelyk D E de Villiers en D J Smit, "Met watter gesag sê u hierdie dinge? Opmerkings oor kerklike dokumente oor die openbare lewe, Skrif en Kerk 16(2), 39-56, vir 'n uitvoerige bespreking van die aanpassings wat die kerk moet mak ten aansien van sy uitsprake oor die openbare lewe in hedendaagse samelewings.
} 
oombiik byvoorbeeld die tendens om slegs korttermyn, reaktiewe maatreëls te neem wat die klem op afskrikking en straf lê, en om langtermyn, pro-aktiewe maatreëls wat op die bevordering van gesonde waardevorming in opvoedkunde instellings (skole, technikons, universiteite), die werkplek, sport, ensovoorts die klem lê, te verwaarloos. Die Afrikaanse kerke behoort pleitbesorgers te wees vir meer langtermyn, pro-aktiewe maatreëls. Hulle behoort veral die ontwikkeling van opvoedkundige programme in skole en ander opvoedkundige instellings wat gesonde waardevorming bevorder, te ondersteun en daaraan mee te werk.

- Die Afrikaanse kerke en hulle lidmate behoort aktief betrokke te wees by inisiatiewe om faktore in die samelewing wat aanleiding gee tot moreel onverantwoordelike optrede, soos armoede, werkloosheid, die ontwrigting van die gesinslewe, en dwelmafhanklikheid te bestry. Die bestryding van hierdie negatiewe faktore behoort in elk geval 'n integrale deel van dié kerke se barmhartigheidsdiens uit te maak. Die feit dat dié faktore ook 'n beduidende bydrae tot die morele krisis lewer, bied egter ekstra motivering vir die effektiewe bestryding daarvan.

- Die Afrikaanse kerke behoort hulle morele steun te gee aan openbare instellings soos die polisiediens, howe en korrektiewe dienste wat verantwoordelik is vir die handhawing van wet en orde in die samelewing en op die oomblik onder baie druk verkeer. Veral lede van die polisiediens is gedemoraliseer oor die negatiewe publisiteit wat hulle kry. Om hierdie negatiewe ingesteldheid te help bestry, kan 'n aantal gemeentes byvoorbeeld 'n polisiekantoor in hulle omgewing "aanneem" en die personeel geestelik en moreel bystaan.

- Daar is reeds daarop gewys dat die Afrikaanse kerke vandag minder geleentheid het om 'n invloed op die openbare lewe uit te oefen, maar dat lidmate nog steeds die geleentheid het om in die politiek, die ekonomie en die kulturele lewe 'n sterk positiewe invloed uit te oefen. Baie lidmate beklee leiersposisies op dié terreine. Lidmate het gevolglik 'n besondere verantwoordelikheid om op alle lewensgebiede (die werkplek, sportlewe, verenigingslewe, gesinslewe, vriendskapskringe) modelle te wees van moreel deugsame mense wat steeds in hulle optrede voorrang gee aan morele oorwegings. 


\subsection{Morele vorming van lidmate}

- Stanley Hauerwas en ook ander teoloë wat die belang van 'n deugde-etiek naas 'n pligte-etiek beklemtoon, het ons geleer dat ook gewone kerklike praktyke soos die erediens, die bediening van die sakramente, gebed, kategese, Bybelstudie en barmhartigheidsdiens sterk morele vormingskrag het. ${ }^{7}$ Dit is egter nie vanselfsprekend dat dié praktyke positiewe morele vorming tot gevolg het nie. Dit kan ook morele wanvorming tot gevolg hê (vgl Smit 1997:272-274; Mudge 1998:91-92). Dit kan gebeur as 'n oordrewe piëtistiese ingesteldheid in die gemeentelike lewe daartoe lei dat die politiek of die kunste as verbode terreine vir Christene beskou word. Dit kan ook gebeur as negatiewe waardes soos rassevooroordeel en materialisme uit die samelewing oorgeneem, in die prediking as Christelik gelegitimeer word of op 'n meer subtiele wyse die gemeentelike lewe deursuur. Die Afrikaanse kerke moet bereid wees om selfkritiek te beoefen en vas te stel of hulle eie organisatoriese strukture, spiritualiteit, boodskap en programme die vermoë van hulle lidmate om moreel verantwoordelik op te tree in gemeentes, maar ook in hulle huwelike, gesinslewe, werk en die openbare lewe in die algemeen, versterk of verswak. Veral moet vasgestel word of die sosiale verantwoordelikheid van hulle lidmate daardeur bevorder word of nie. Hulle moet egter nie met die selfkritiek volstaan nie. Die besondere potensiaal van die erediens en ander kerklike praktyke om moreel positiewe waardes en houdings by lidmate te vestig, moet volledig ontgin word (vgl Smit 1997:261-264; Mudge 1998:81).

- Afrikaanse kerke moet die moed hê om nie alleen die openlik immorele gedrag van hulle lidmate te veroordeel nie, maar ook die negatiewe ingesteldhede, oortuigings en waardes wat bydra tot morele onverantwoordelikheid. Rassistiese houdings, 'n onwilligheid om vrede te maak met die nuwe konstitusionele bedeling en die aanname dat dinge in Suid-Afrika onafwendbaar slegter sal gaan, is voorbeelde van ingesteldhede en oortuigings wat dit feitlik onmoontlik maak vir lidmate om hulle sosiale verantwoordelikheid na te kom (vgl De Villiers 1999:29-30). 'n Rassistiese

\footnotetext{
7 Vergelyk die opmerking van Mudge (1998:43): "If the community of faith is the primary source of moral consciousness, then everything about that community's life, not just specific commandments or ethical reflection as such, contributes to that end." Teoloë in Suid-Afrika wat 'n sterk pleidooi vir 'n deugde-etiek gevoer het, is Neville Richardson ( $\mathrm{vgl}$ sy Ethics of character and community, in C Villa-Vicencio \& J de Gruchy (eds), Doing ethics in context: South African perspectives, 89-101), Robert Vosloo (vgl sy Back to virtue? Some remarks on the reappraisal of virtue in ethics. Scriptura 62(3), 191-210) en Dirk Smit (vgl sy Liturgy and life? On the importance of worship for Christian ethics, Scriptura 62(3), 259-280).
} 
ingesteldheid en 'n hunkering terug na 'n politieke bedeling waarin die meerderheid burgers nie ' $n$ sê in die sentrale regering gehad het nie, is in stryd met die Bybelse norme van liefde en geregtigheid. Die aanname dat dinge onafwendbaar slegter sal gaan, is uitdrukking van 'n onaanvaarbare determinisme wat in stryd is met die Christelike geloof in die voorsienige sorg van 'n liefdevolle Vader. Daarom moet sulke ingesteldhede en oortuigings profeties veroordeel word.

- $\quad$ Nog 'n faktor wat dit vir lidmate van die Afrikaanse kerke moeilik maak om 'n konstruktiewe rol in die nuwe Suid-Afrika te speel, is die vlotte ontkenning by baie van hulle dat hulle enige skuld het aan die onreg van apartheid. Hulle is geneig om óf te ontken dat apartheid mense onreg aangedoen het, óf te ontken dat hulle self enige aandeel aan die onreg van apartheid gehad het. Om te ontken dat apartheid mense onreg aangedoen het, is egter in die lig van al die getuienis wat aan die lig gekom het, 'n flagrante verdraaiing van die waarheid. Dat mense wat die apartheidsbeleid nooit veroordeel het nie en verkiesing na verkiesing vir die Nasionale Party of ' $n$ nog meer nasionalistiese party gestem het - kan beweer dat hulle geen aandeel aan die onreg van apartheid het nie, is egter net so ongeloofwaardig. Wat in dié verband egter van besondere belang is, is dat mense wat so vanselfsprekend enige verantwoordelikheid vir die onreg van die verlede van hulle afskuif ook nie bereid is om hulle morele verantwoordelikheid in die hede te aanvaar nie. Hulle is so besig om hulleself te verontskuldig, om die skuld vir die verlede op ander af te skuif, om hulle te verknies oor die "onreg" wat hulle in die hede aangedoen word, en die huidige regering vir al die probleme wat ons in die land ervaar, te blameer dat hulle nie die wil, die tyd en die energie het om 'n opbouende rol in die huidige samelewing te speel nie. ${ }^{8}$ Die Afrikaanse kerke sal sulke lidmate moet help om in die reine te kom met hulle eie skuld aan wat in die verlede gebeur het, en hulle moet motiveer om hulle verantwoordelikheid vir die morele genesing van ons samelewing na te kom.

- Mense tree nie net moreel onverantwoordelik op omdat hulle onwillig is om hulle skuld aan apartheid te erken en te verwerk nie, maar ook omdat hulle met

\footnotetext{
8 In die roman, The Reader, skryf Bernhard Schlink treffend oor die onwilligheid van 'n vorige geslag Duitsers om enigsins verantwoordelikheid te neem vir die verdrukking van die Jode voor en tydens die Tweede Wêreldoorlog en oor die opstand van hulle kinders juis omdat hulle nie bereid was om verantwoordelikheid te aanvaar nie.
} 
onverwerkte haat- en skuldgevoelens sit oor wat ander hulle of hulle ander in persoonlike verhoudinge aangedoen het. Om sulke lidmate te help om moreel verantwoordelik in hulle huwelike, gesinne en werkplek op te tree, sal die kerk die nodige pastorale hulpdienste beskikbaar moet stel.

- Een van die ingrypende gevolge van die moderniseringsproses is dat waardes wat ten grondslag lê van die hedendaagse ekonomie, so dominant geword het dat hulle ook deur die lidmate van kerke en selfs deur kerke oorgeneem en uitgeleef word. In die bespreking van die oorsake van die huidige morele krisis is reeds daarop gewys dat die materialistiese waardes van die vryemarkekonomie onkrities deur lidmate en kerke oorgeneem word. Die Afrikaanse kerke sal hierdie materialistiese waardes wat 'n integrale deel van die lewenstyl van hulle lidmate geword het en ook die kerklike lewe deursuur, moet konfronteer. 'n Poging moet aangewend word om die kerklike lewe van dié waardes te suiwer en leiding moet aan lidmate gegee word om 'n lewenstyl te ontwikkel wat meer in ooreenstemming met die morele waardes van die evangelie van Jesus Christus is.

- $\quad$ Morele deugde word veral gevorm tydens die kinder- en jeugjare. ${ }^{9}$ Daarom is dit van belang om ook in kerklike verband besondere aandag aan die morele vorming van kinders en jongmense te gee. Aangesien die ouerhuis die belangrikste kweekplek van morele deugde is, behoort die Afrikaanse kerke programme van hoë kwaliteit te ontwikkel om ouers in die morele en godsdienstige opvoeding van hulle kinders by te staan. Besondere aandag behoort ook aan die kategese en jeugwerk van gemeentes gegee te word om te verseker dat dit wel 'n sterk en positiewe bydrae lewer tot morele vorming.

- $\quad$ Een van die mees effektiewe maniere waarop morele deugde by kinders, maar ook by volwassenes gevorm word, is dienslewering. Baie meer aandag behoort daarom gegee te word aan die implementering van diensprogramme en die inskakeling by bestaande diensprogramme van ander gemeentes en kerke om lidmate in staat te stel om prakties sosiale verantwoordelikheid te beofen en so hulle motivering en vermoë om dit te beoefen, te versterk.

\footnotetext{
${ }^{9}$ Volgens Van der Ven (1998:43-124) speel veral dissipline en sosialisering 'n belangrike rol in die morele vorming van kinders in die ouerhuis.
} 
- Aandag moet egter nie net aan die vorming van morele deugde gegee word nie. Dit word toenemend belangrik dat lidmate die vermoë ontwikkel om selfstandig die regte morele besluite te neem. ${ }^{10}$ Dit is relatief maklik om in die gemeente eenstemmigheid te kry oor wat die morele beginsels is wat Christene in hulle morele besluitneming moet lei. Dit is egter veel moeiliker om hierdie beginsels in konkrete lewensituasies toe te pas en verantwoorde morele besluite te neem. Dit is dikwels nie die geval van 'n keuse tussen reg en verkeerd nie, maar van 'n keuse tussen reg en reg, of van ' $n$ keuse tussen verkeerd en verkeerd. Daarby kom ook nog dat lidmate in die werkplek en op die sportveld toenemend gekonfronteer word met die uiteenlopende morele menings van mense met ander lewensbeskouinge. Dit is daarom van die grootste belang dat hulle met die vaardigheid van selfstandige morele besluitneming toegerus word. Een van die maniere waarop dié toerusting kan geskied, is vir gemeentes om 'n forum te bied waar al die morele probleme waarmee lidmate in hulle huwelike, gesinne, die werkplek en die openbare lewe gekonfronteer word en hulle verontrus, op 'n gereelde grondslag bespreek word. Aangesien die werkplek een van die brandpunte in ons huidige morele krisis is, behoort die Afrikaanse kerke ook programme van 'n hoë kwaliteit oor "Morele verantwoordelikheid in die werkplek" te ontwikkel en aan te bied om lidmate by te staan in die hantering van morele dilemmas waarmee hulle gekonfronteer word in die werkplek en om hulle vermoë om daar moreel verantwoordelik op te tree, te versterk. Sulke programme behoort ook aandag te gee aan die vestiging van 'n gesonde werksetiek by lidmate.

- Die Afrikaanse kerke moet lidmate wat voel dat dinge op morele terrein, nie net in die samelewing nie, maar ook in die kerk gly, omdat daar veel meer onsekerheid en verdeeldheid is oor wat moreel reg en verkeerd is (bv oor homoseksualiteit, aborsie en die staatslotery) beter begelei. Sulke lidmate moet gehelp word om twee versoekinge in 'n situasie van groter morele onsekerheid te weerstaan: fundamentalisme en relatiwisme. Sommige lidmate is geneig om op die situasie van groter morele

\footnotetext{
${ }^{10}$ Die Duitse etikus, Eduard Tödt, se onderskeiding van 6 logiese stappe in die proses van morele oordeelsvorming bied ' $\mathrm{n}$ handige hulpmiddel wat by die bespreking van aktuele morele kwessies benut kan word. ' $n$ Bespreking van dié 6 stappe in Afrikaans aan die hand van die voorbeeld van morele besluitneming oor die probleem van armoede word deur D E de Villiers en D J Smit gebied in: Waarom verskil ons so oor wat die wil van God is? Opmerkings oor Christelike morele oordeelsvorming, Skrif en Kerk 17(1), 31-47.
} 
onsekerheid te reageer deur halsstarrig vas te klou aan tradisionele morele oortuigings en hulle eenvoudig af te sluit van enige bevraagtekening van die tradisie. Ander weer is geneig om alle tradisionele morele oortuigings oorboord te gooi en die standpunt in te neem dat niemand se beskouing meer reg is as dié van ander nie. Lidmate moet gehelp word om te onderskei tussen wat onopgeeflik is in die Christelike geloof en moraliteit is en daarom gehandhaaf moet word en wat nie onopgeeflik is nie en waaroor gesprek en verskil moontlik en aanvaarbaar is.

- Mense wat wanhoop en geen vertroue meer in die toekoms het nie, is veel meer blootgestel aan die versoeking om immoreel op te tree. Daarom is dit so belangrik dat die Afrikaanse kerke die Bybelse boodskap van hoop en die betekenis daarvan in die huidige Suid-Afrikaanse samelewing effektief aan hulle lidmate kommunikeer. Dit is alleen as lidmate hoop het vir die toekoms dat hulle ook bereid en in staat sal wees om hulle morele verantwoordelikheid in ons samelewing na te kom ( $\mathrm{vgl}$ Mudge 1998:126).

\section{SLOTWOORD}

Dit het in die artikel geblyk dat die gelaat en die oorsake van die huidige morele krisis in die Suid-Afrikaanse samelewing meer-dimensioneel van aard is. Daarom behoort ook die bydrae van die Afrikaanse kerke tot die morele krisis van ons samelewing meer-dimensioneel te wees. Die besondere situasie van die Afrikaanse kerke plaas, aan die een kant, sekere beperkinge op die bydrae wat hulle kan lewer. Aan die ander kant plaas dit dié kerke voor besondere en eiesoortige uitdagings. Indien hulle hulle roeping om omvattende koninkryksdiens in die Suid-Afrikaanse samelewing te lewer, wil nakom, sal hulle hierdie uitdagings met moed en takt moet aanpak.

\section{Literatuurverwysings}

De Dijn, H 1997. Hoe overleven we de vrijheid? Modernisme, postmodernisme en het mystiek lichaam. Kapellen: Uitgeverij Pelckmans.

De Villiers, D E \& Smit, D J 1995. “Met watter gesag sê u hierdie dinge?” Opmerkings oor kerklike dokumente oor die openbare lewe. Skrif en Kerk 16(1), 39-56. 
De Villiers, D E \& Smit, D J 1996. Waarom verskil ons so oor wat die wil van God is? Opmerkings oor Christelike morele oordeelsvorming. Skrif en Kerk 17(1), 31-47.

De Villiers, D E 1999. Die N G Kerk en die oorgang na 'n nuwe Suid-Afrika. Skrif en Kerk 20(1), 15-38.

Esterhuyse, W C 1999. Die baie gesigte van korrupsie. Beeld 10 Maart.

Grondwetlike Vergadering 1996. Die grondwet van die Republiek van Suid-Afrika, 1996.

Hauerwas, S 1977. Faithfulness and tragedy. Notre Dame: Notre Dame UP.

- 1991. After Christendom. Nashville: Abingdon.

Moltmann, J 1974. Man: Christian anthropology in the conflicts of the present. Philadelphia: Fortress Press.

Mudge, L S 1998. The church as moral community: Ecclesiology and ethics in ecumenical debate. New York: Continuum.

Painter-Morland, M 1999. Dealing with "difference": An alternative approach to "Western" and "African" values in the South African workplace. Scriptura 69(1), 149-161.

Richardson, N 1994. Ethics of character and community, in C Villa-Vicencio \& J deGruchy (eds), Doing ethics in context: South African perspectives, 89-101. Cape Town: David Philip.

Schlink, B 1997. The Reader. L.onden: Phoenix.

Smit, D J 1997. Liturgy and life? On the importance of worship for Christian ethics. Scriptura 62(3), 259-280.

Van der Ven, J A 1993. Ecclesiologie in context. Kampen: J H Kok.

- 1998. Formation of the moral self. Grand Rapids: Eerdmans.

Van Niekerk, A 1992. Saam in Afrika. Kaapstad: Tafelberg.

Vosloo, R 1997. Back to virtue: Some remarks on the reappraisal of virtue in ethics. Scriptura 62(3), 191-210. 